\title{
Contents, Vol. 11, No. 5-6, 1979
}

Bloeinendal, H. (Nijmegen): Lens Proteins as Markers of Terminal Differentiation. 243

Koch, H.-R. (Bonn): Basic Research on the Crystalline Lens and its Importance for Clinical Ophthalmology. Introductory Lecture 254

Harding, C. V.; Harding, D., and Susan, S. (Detroit, Mich.): Control of Cell Prolifer ation in Rabbit Lens Epithelium 264

Rafferty, N.; Goossens, W., and Roth, A. (Chicago, Ill.): Cytoplasmic Filaments in Aging Lens of Rodents 276

Ramaekers, F.C.S.; Hukkelhoven, M. W.A.C.; Groeneveld, A., and Bloeinendal, H. (Nijmegen): Cytoskeletal Structures in Cultured Bovine Lens Cells and their Role in Lens Cell Elongation 283

Vornhagen, R. and Rink, H. (Bonn): The Influence of Culture Conditions on the Be haviour of Lens Epithelial Cells 288

Iwig, M. and Glaesser, D. (Halle/Saale): Growth Control of Lens Epithelial Cells by Cell-Substratum Interactions and Cell Flattening 293

Iwig, M. and Glaesser, D. (Halle/Saale): On the Role of the Substratum in Cell Shape Variations of Bovine Lens Cells 298 Glässer, D.; Rattke, W., and Iwig, M. (Halle/Saale): Low Doses of Exogenous Adenine, Hypoxanthine, and Guanine Hold G0 Cells from Bovine Lens Epi thelium in the Resting State by Inhibiting Cell Flattening 302 Eguchi, G. and Kodama, R. (Nagoya): A Study of Human Senile Cataract: Growth and Differentiation of Lens Epithelial Cells in in vitro Cell Culture 308

Barritault, D.; Arruti, C.; Whalen, R.G., and Courtois, Y. (Paris): Adult Bovine Epithelial Lens

Cell in Culture. Electrophoretic Pattern of Total Protein on Longterm Cultures and Morphological Changes Induced by a Retinal Extract 316

Bergner, A, and Glässer, D. (Halle/Saale): Demonstration of a Magnesium- and Calcium-Dependent ATPase on the Outer Surface of Bovine Lens Epithelial Cells 322

Clayton, R.M. (Edinburgh): Regulatory Factors for Lens Formation in Cell Culture.

I. Possible Requirement for Pre-Existing Levels of Crystallin mRNA 324 Clayton, R.M. (Edinburgh): Regulatory Factors for Lens Fibre Formation in Cell Culture. II. The Role of Growth Conditions and Factors Affecting Cell Cycle Duration 329

Tréton, /.; Modak, S., and Courtois, Y. (Paris/Lausanne): DNA Repair in the Lens 335 Francois, J.; Víctoria-Troncoso, V.; Cansu, K., and Lentini, F. (Gent): Morphological and Microcinematographical Tissue Culture Study of the Differentiation of Adult Lens Epithelial Cells into Fibres $\quad 341$ Contents

240

Bours, J.; Zauzig, H.-D., and Rink, H. (Bonn): Crystallin Composition of the Bovine 
Lens Epithelium Related to Aging. Immunoelectrophoresis 351

Rink, H. and Vornhagen, R. (Bonn): Crystalline of Lens Epithelial Cells during Aging and Differentiation 355

Delcour, J. and Pierssens, A.-M. (Louvain-la-Neuve): Sensitivity of Polysomes to Endonucieolytic Cleavage in Relation with Aging in Bovine Lens Fiber Cells. 360 Takáts, A.; Antoni, F., and Faragó, A. (Budapest): Changes of the cAMP-Dependent Protein Kinases during Differentiation of Lens Cells 366

Lasch, J. (Halle/Saale): Kinetic Properties of Bovine Lens Leucine Aminopeptidase 372 Müller-Frohne, M. (Halle/Saale): Leucine Aminopeptidase from Bovine Eye Lens.

Studies on the Active Centre by Chemical Modification Techniques 377

Fittkau, S.; Kämmerer, G., and Damerau, W. (Halle-Saale/Berlin-Buch): The Binding Center of Leucine Aminopeptidase. Investigations with Substrate Analogous and Spin-Labelled Inhibitors 381

Klante, K.-P.; Mqotsi, S., and Fittkau, S. (Halle/Saale): Leucine Aminopeptidase from Bovine Eye Lens. Affinity Labelling of the Enzyme with Diazopeptide Inhibitors $\quad 386$

Hockwin, O. and Ohrloff, C. (Bonn): Ageing of Lens Metabolism 389

Duncan, G. and Bushel!, A.R. (Norwich): Relationships between Colour, Sodium and Protein Content in Individual Senile Human Cataractous Lenses 397

Hockwin, O.; Dragomirescu, V., and Koch, H.-R. (Bonn): Photographic Documen tation of Disturbances of the Lens Transparency during Ageing with a Scheimpflug Camera System 405

Pallai, G.; Rácz, P., andBelágyi, J. (Pécs): Investigations on Normal and Cataractous Human Lenses by EPR 411

Cavalli, L.; Galaverni, D.; Pesando, P.; Bracchi, P.G.; Campanini, G., and Maraini, G. (Parma): Control of Ribonuclease Activity in the Human Lens during Ageing and Cataract Formation 416 Broekhuyse, R.M.; Kuhlmann, E.D., and Jap, P.H.K. (Nijmegen): Lens Membranes.

IX. Some Characteristics of Fiber Membranes in Relation to Ageing and Cataract Formation 423

Harding, J.J. (Oxford): Aggregation of Proteins in Human Cataract 429

Haard, P.M.M. van; Martens, G.J.M.; Mestrom, J.J.L.; Hoenders, H.J., and Wollensak, J. (Nijmegen/Berlin): Very Acidic Polypeptide Chains from Old Human Eye Lenses 433

Bindels, J.G.; Siezen, R.J., and Hoenders, H.J. (Nijmegen): A Model for the Architecture of «-Crystallin 441

Hockwin, O.; Bergeder, H.-D.; Herrmann, R., and Walter, S. (Bonn): Investigations on the Heat Lability of the Phosphofructokinase (EC 2.7.1.11) in Bovine Lenses after X-Irradiation and under Various Incubation Conditions 453

Korte, I. and Klein, W. (Bonn-München-Neuherberg): Heat Lability of Enzymes of Bovine Lenses after in vitro Incubation in the Presence of Polychlorinated

Phenols 461

Author Index 466

Subject Index 468

Contents to Vol. 11 after 470 